${ }^{2}$ Emberger J M, Rodiere M, Astruc J, Brunel D. Syndrome de Prader Willi et translocation 15/15. Ann Genet (Paris) $1977 ; 20$ : 297-300.

3 Fraccaro M, Zuffardi O, Buhler E M, Jurik L P. 15/15 translocation in Prader Willi syndrome. J Med Genet $1977 ; 14: 275-8$.

4 Smith A, Noel M. A girl with the Prader Willi syndrome and Robertsonian translocation $45, X X, t(14 ; 15)$ (p11.q11) which was present in 3 normal family members. Hum Genet $1980 ; 55$ : 271-3.

5 Kucerová M, Straková M, Polivková Z. The Prader Willi syndrome with a $15 / 3$ translocation. J Med Genet 1979; 16: 234-5.

- Subrt I, Blehová B. Robertsonian translocation between chromosome $Y$ and 15. Hum Genet 1974; 23 : 305-9.

7 Le Jeune J, Maunoury C, Prieur M, Van der Akker J. Translocation sauteuse $(5 p ; 15 q),(8 q ; 15 q),(12 q ; 15 q)$. Ann Genet (Paris) 1979; 22: 210-3.
8 Ledbetter D H, Riccardi V M, Airhart S D, Strobel R J, Keenan B S, Crawford J D. Deletions of chromosome 15 as a cause of the Prader Willi syndrome. $N$ Engl J Med $1981 ; 304: 325-8$.

9 Wisniewski L P, Witt M E, Ginsberg-Fellner F, Wilner J, Desnick R J. Prader Willi syndrome and a bisatellited derivative of chromosome 15. Clin Genet 1980; 18: 42-7.

10 Bartsch-Sandhoff M. Letter: Fusion of homologous chromosomes (15q.15q) as cause of recurrent abortion. Lancet 1977; i: 551 .

Correspondence to Dr A Caroline Berry, Prince Philip Research Laboratories, Paediatric Research Unit, Guy's Tower, 8th Floor, St Thomas Street, London SE1 9RT.

Received 30 March 1981

\title{
Galactosaemia: a new severe variant due to uridine diphosphate galactose-4-epimerase deficiency
}

\section{J B HOLTON, M G GILLETT, R MACFAUL, AND R YOUNG}

\section{Department of Clinical Chemistry, Southmead Hospital, Bristol, and Department of Paediatrics and Department of Biochemistry, Pinderfields Hospital, Wakefield}

SUMMARY A baby presented on day 5 with symptoms of classical galactosaemia which are believed to be owing to a lack of uridine diphosphate-4-epimerase, rather than to the usual galactose-1-phosphate uridyl transferase defect. Apart from galactosaemia the condition was characterised biochemically by a red cell accumulation of galactose-1phosphate and uridine diphosphate galactose. Galactose restriction modified the acute clinical and biochemical abnormality, but it appears essential to include some galactose in the diet in this condition to allow synthesis of galactosides, including the brain gangliosides.

Classical galactosaemia which is caused by a deficiency of the enzyme galactose-1-phosphate uridyl transferase (transferase) often presents in the neonatal period with a severe illness characterised by vomiting, jaundice, failure to thrive, and hepatosplenomegaly, associated with excess of reducing substances in the urine. ${ }^{1}$ We wish to report a baby who presented on the fifth day of life with symptoms of classical galactosaemia apparently owing to an inherited deficiency of a different enzyme-namely, uridine diphosphate galactose-4-epimerase (epimerase). We know of no other reported case.

\section{Case report}

The patient, a girl, was born at term weighing $2490 \mathrm{~g}$ and was bottle fed from birth. She was the second child of a consanguineous marriage in a Pakistani family, the fathers of the parents being step-brothers with the same father. Jaundice, with a total serum bilirubin concentration of $121 \mu \mathrm{mol} / 1(7 \cdot 1 \mathrm{mg} / 100$ $\mathrm{ml})$ and direct of $37 \mu \mathrm{mol} / \mathrm{l}(2 \cdot 2 \mathrm{mg} / 100 \mathrm{ml})$, associated with secondary weight loss, was noted on the fifth day of life. The next day there was further weight loss, she became hypotonic, and had $0.75 \%$ reducing substances in her urine. On the ninth day occasional vomiting occurred, with continuing weight loss, jaundice, and hypotonia, and the liver edge was firm $-1 \mathrm{~cm}$ below the costal margin. Routine investigation of blood and CSF was normal, but galactose was found in the urine at a concentration of $116 \mathrm{mmol} / 1(2.09 \mathrm{~g} / 100 \mathrm{ml})$ and about this time a moderate generalised aminoaciduria was reported. The baby was given intravenous dextrose and, with a presumptive diagnosis of galactosaemia, was started on a low lactose diet in the form of Nutramigen feeds. The jaundice settled, liver function tests became normal, and she thrived from the 10th to 44th days of life. The Beutler screening test for transferase deficiency ${ }^{2}$ was negative on the 16th day of life and therefore she was challenged with Cow and Gate V formula for $2 \frac{1}{2}$ days, starting on the 44th day. Galactosuria returned within 24 hours and the serum transaminases became greatly increased with ALT $1473 \mathrm{U} / 1$ and AST $1218 \mathrm{U} / 1$ (normal values up to 48 and 43 respectively). Jaundice reappeared 
after 2 days and she became floppy, uninterested in feeds, and she developed hepatomegaly. On resumption of the Nutramigen feeds the jaundice faded, she became well, and liver enzymes returned to normal during the next 20 days. At age 3 months a further challenge was made with pure galactose added to Nutramigen feeds. On a regimen including $4 \mathrm{~g}$ galactose a day she remained well for 2 days, but on increasing it to $12 \mathrm{~g}$ a day she became clinically unwell and the supplements were stopped after 15 hours on the higher dose. A slight increase in serum ALT was noted at the end of the galactose challenge.

\section{Results}

The Beutler screening test for classical galactosaemia proved negative on several occasions but, since galactose seemed to be the direct cause of the patient's symptoms, further studies of the red cell enzymes concerned in galactose metabolism were made.

Quantitative estimation of transferase $^{3}$ was normal as were the qualitative properties of the enzyme using isoelectric focusing (M Gillett, 1980, unpublished observations). The level of galactokinase $^{4}$ was also within the normal range. However, the estimation of epimerase ${ }^{5}$ showed an almost complete lack of activity in the patient and reduced levels in her mother and father (Table). Epimerase deficiency was shown too in the patient's skin fibroblasts.

Abnormal quantities of galactose metabolites were present in the patient's red blood cells. Galactose-1-phosphate (gal-1-P) was measured ${ }^{6}$ on different dietary intakes of galactose and varied from zero to $305 \mu \mathrm{mol} / 1(7.9 \mathrm{mg} / 100 \mathrm{ml})$ on 1.5 and $4.0 \mathrm{~g}$ galactose daily respectively. The substrate of epimerase, uridine diphosphate galactose (UDPGal), was shown to accumulate up to a concentration of $105 \mu \mathrm{mol} / 1(5.9 \mathrm{mg} / 100 \mathrm{ml})$ on $4.0 \mathrm{~g}$ galactose daily, normal levels are zero (M J Henderson, 1981, unpublished observations).

Table Erythrocyte epimerase aciivity in the patient and her parents

\begin{tabular}{ll}
\hline Subjects & $\begin{array}{l}\text { Enzyme activity } \\
(\mu \mathrm{mol} / \mathrm{h} \text { per ml red blood cells })\end{array}$ \\
\hline Patient & $0 \cdot 1$ \\
Mother & $0 \cdot 9,1 \cdot 1$ \\
Father & $2 \cdot 5$ \\
Control group & Mean $=4 \cdot 63, \mathrm{SD}=1 \cdot 08$ \\
$(\mathrm{n}=17)$ & $($ range $3 \cdot 0-6 \cdot 2)$ \\
Report of control group5 & Mean $=4 \cdot 90, \mathrm{SD}=1 \cdot 17$ \\
$(\mathrm{n}=32)$ & $($ range $2 \cdot 7-7 \cdot 9)$ \\
\hline
\end{tabular}

(A)

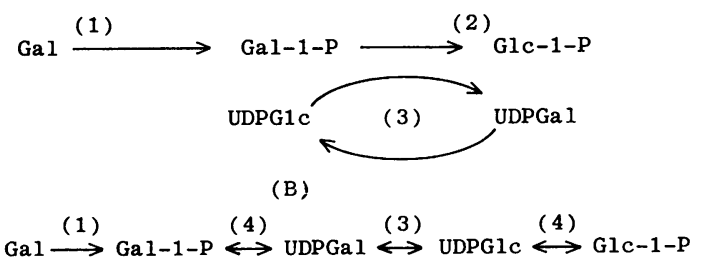

(1) Galactokinase

(2) Galactose-1-phosphate uridyl transferase

(3) Uridine diphosphate galactose-4-epimerase

(4) Pyrophosphorylase

Figure (A) Main pathway of galactose metabolism. (B) Alternative (pyrophosphorylase) pathway of galactose metabolism.

\section{Discussion}

There are two pathways for the metabolism of galactose in humans, ${ }^{1}$ and epimerase is a key enzyme in both. The main route (Figure (A)) involves direct conversion of gal-1-P to glc-1-P by the enzyme transferase. This requires UDPGlc as a cofactor which is converted to UDPGal during the course of the reaction. Epimerase is necessary to regenerate UDPGlc from UDPGal, thus allowing the cons tinued activity of transferase. An alternative pathway has been described (Figure (B)) to explain how somè galactose can be metabolised in older patients with classical galactosaemia, in whom the main pathway is blocked because of transferase deficiency. However, it will be seen later that the pathway is probably of greater significance in its reverse direction in these patients.

Some individuals have been reported previously with an inherited deficiency of red blood cell epimerase. $^{17}$ However, they had appreciable amounts of epimerase activity in skin fibroblasts, lymphocyte cultures, and liver, and they were clinically normal. We consider that the data in the present case point to the existence of a different mutation resulting in a complete enzyme deficiency and a severe clinical disorder. The finding of quite high levels of red cell gal-1-P on a moderate intake of galactose supports the concept. This compound is thought to be the most toxic metabolite occurring in classical galactosaemia and could account for the severe symptoms in the patient if its accumulation is widespread. An important conclusion from these observations is that a serious disorder of galactose metabolism cannot be completely excluded by testing for transferase defect alone.

Galactose is an essential constituent of the 
sphingolipids required for brain growth and development, and for many other galactosides. The galactose is incorporated into these compounds through the cofactor UDPGal. In a normal or transferasedeficient individual, UDPGal can be synthesised even when galactose intake is restricted. This is achieved from glc-1-P by reversal of the pyrophosphorylase pathway. The patient, who is believed to have an epimerase deficiency, is unable to make UDPGal by this means and is dependent on galactose for its synthesis. Therefore, while her galactose intake has to be restricted to prevent acute symptoms developing, it is essential that she has some dietary galactose to allow UDPGal and galactoside synthesis.

Since age 4 months the patient has been maintained on a galactose intake of $1.5 \mathrm{~g}$ daily. On this regimen the red blood cell gal-1-P is about zero and the UDP galactose has fallen to $55 \mu \mathrm{mol} / 1(3 \cdot 1 \mathrm{mg} / 100 \mathrm{ml})$. However it is not clear whether the circulating red cell is a good indicator of the availability of UDPGal in all tissues. Her developmental progress is causing some concern since she did not smile until 8 weeks of age and at 6 months her development was only at a 4-month stage.

We thank the clinical and laboratory staff who assisted with the investigations.
References

1 Gitzelmann R, Hanson R G. Galactose metabolism, hereditary defects, and their clinical significance. In: Burman D, Holton J B, Pennock C A, eds. Inherited disorders of carbohydrate metabolism. Lancaster: MTP Press, 1980: 61-101.

2 Beutler E, Baluda M. A simple spot screening test for galactosemia. J Lab Clin Med 1966; 68: 137-41.

3 Monk A M, Mitchell A J H, Milligan D W A, Holton J B. Diagnosis of classical galactosaemia. Arch Dis Child 1977; 52: 943-6.

4 Ng W G, Donnell G N, Bergren W R. Galactokinase activity in human erythrocytes of individuals at different ages. J Lab Clin Med 1965; 66: 115-21.

5 Gitzelmann R, Steinmann B. Uridine diphosphate galactose 4-epimerase deficiency. II. Clinical follow-up, biochemical studies, and family investigation. Helv Paediatr Acta 1973; 28: 497-510.

6 Kirkman H N, Maxwell E S. Enzymatic estimation of erythrocytic galactose-1-phosphate. J Lab Clin Med 1960; 56: $161-6$.

7 Ichiba Y, Namba N, Nisumi H. Letter: Uridine diphosphate galactose 4-epimerase deficiency. Am J Dis Child $1980 ; 134: 995$.

Correspondence to Dr J B Holton, Department of Clinical Chemistry, Southmead Hospital, Westbury-on-Trym, Bristol BS10 5NB.

Received 8 June 1981
SUMMARY Four different treatments for the care of the umbilical cord were compared in a randomised, controlled study. Triple dye was associated with a significantly earlier separation of the cord than either $1 \%$ neomycin or $1 \%$ silver sulphadiazine ointment, and it was nearly as effective as bismuth subgallate (an astringent powder) in causing rapid sloughing. If the mother is made aware that care of the umbilical cord may delay cord separation she may be spared unnecessary concern.

A delay in the separation of the umbilical stump is often a cause of maternal concern; such concern can often be prevented if a proper explanation is given. New methods of treating the umbilical cord are now used in the control of neonatal bacterial colonisation. ${ }^{12}$ Four different types of treatment were compared in order to find out what advice should be given to the mother.

\section{Subjects and methods}

Healthy, appropriate-for-gestational age, term infants, who had been admitted to our nursery between January and July 1980, were each randomly assigned to one of four treatment regimens. Informed parental consent was obtained. The four regimens were:

(1) Triple dye (brilliant green, $2 \cdot 29 \mathrm{~g}$; proflavine hemisulphate, $1 \cdot 14 \mathrm{~g}$; crystal violet, $2 \cdot 29 \mathrm{~g}$; and sufficient water to make $1000 \mathrm{ml}$ ). 